\title{
J-STAGE
}

原著論 文

\section{畳み込みニューラルネットワークを用いて果実 画像の生育度分類を行う場合の果実拡大率の影響}

\author{
源野広和 $* 1)$ ，小林一樹 2 ) \\ 1）キッセイコムテック株式会社％ 390-1293＼cjkstart長野県松本市和田 4010-10

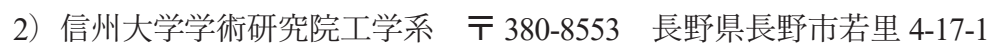

\begin{abstract}
要旨
本研究では, 畳久込久ニューラルネットワーク（CNN）を用いて果実画像の生育度分類を行う場合に，果実拡 大率の影響を明らかとする。生育度分類に用いた果実画像は, リンゴのふじとあいかの香りであり，果実が膨ら 久だした時期から收穫直前まで約 2 週間毎に撮影し，撮影日に基づく生育度を数值としてクラス設定した，果実 画像の果実拡大率は，0.462-6.000 倍の範囲で13 段階に設定して，果実拡大率毎に学習を行った，学習済 CNN を 用いてテスト用画像を分類した結果, 果実拡大率は, ぶ゙で 0.545 と 1.000 の時に, あいかの香りで $0.500,0.600,1.000$ の時に, 正解率が高くなった。 また, 両品種とも, 果実拡大率が 1.000 から増加するにともなって正解率が減少した. これらから，CNN が生育度分類を行う際には，果実の輪郭や周辺領域を参照して和り，また，果実全体の色彩分 布を参照していると推察された. 両品種ともに, 果実拡大率 1.000 のときに正解率が高かったことから, 本研究では, スマートフォンで果実を撮影した時に, 果実拡大率が約 1 倍になる果実画像が自動で切り出され, 推定生育度が 自動表示される生育評価アプリケーションを例示した.
\end{abstract}

キーワード

深層学習, 畳又込久ニューラルネットワーク, 生育評価, アプリケーション, リンゴ, 果実画像

\section{はじめに}

リンゴ果実の生育評価は, サイズや色彩を指標にして行 われている。 サイズについては，果実が膨らみだしてから 成熟するまでの期間を対象として, 果実が肥大するしくみ に関する研究（山本ら 1996，福田，森山 1997，新居 1998） や果実を肥大させる研究 (小池ら 1990, 守谷ら 2016) が 行わ水, 直径や重量が計測されている. しかし, 多くの果 実に対して精度よく直径や重量を計測する作業は，人的負 担が大きい作業である，そこで著者らは，定点計測したり ンゴ樹画像から葉面積を算出し, 累積葉面積から果実半径 を推定する方法を提案した（源野，小林 2017, Genno and Kobayashi 2019). しかし, この方法は, 人的作業が不要な

\footnotetext{
* Corresponding Author

E-mail: genno@comtec.kicnet.co.jp
}

反面，定点計測を前提にしているために柔軟性が低い．

色彩については，リンゴ果実は成熟すると色彩が変化す るため, 色彩で成熟判断する方法が提案されている. 例兄 ば，リンゴ果実の着色をカラーチャートと比較する方法は (草田ら 2016), 主観に上る判断であり客観性の問題があ る. また, 定点計測した画像中のリンゴ果実の RGB 比率 で成熟評価する方法や (岸ら 2010), リンゴ果実の糖・酸 含量を近赤外分光計測法で評価する方法は（宮本 2007）, いずれも高価な機器が必要である.

また, 個々の果実が含まれる正方形画像を切り出して, 畳及込みニューラルネットワーク（CNN）に入力して， トマト（Zhang et al. 2018）やウメ（建本ら 2019）の成熟度 を分類する方法が提案されている. 画像から果実の大きさ を計測できないことから，これらの方法は色彩に基づく成 熟評価を行っていると推察される. しかし, 色彩の久を指 標にしているなら, 果実表面の微細な色合いやテクスチャ 
を拡大して，周辺領域を全く含まない画像を入力すれば精 度が高末る可能性がある。 また，周辺領域を参照して成熟 評価を行っているなら，果実部分を縮小し，周辺領域を大 きく含む画像を入力すれば精度が高まる可能性がある。し かし, このような果実拡大率の影響を検証した研究は行わ れてこなかった。

そこで本研究では，CNNを用いて果実画像の生育度分 類を行う場合に，CNN に入力する画像に果実全体が皃ぼ 過不足なく含まれるように果実画像を拡大もしくは縮小し た時の果実拡大率を 1 と定義した。 そして，果実拡大率を 0.462-6.000 倍の範囲で変化させて, 分類精度に対する果 実拡大率の影響を評価したので報告する。また，スマート フォンで果実画像を撮影した時に, あらかじめ設定された 拡大率で果実画像が切り出され，その画像を用いて学習済 CNN が生育度を推定し, 推定生育度が自動表示されるア プリケーションの例を示す。

\section{生育度の分類精度に対する果実拡大率の影響調 查}

\section{果実拡大率の異なる画像セットの作成 撮影条件}

本研究では, リンゴ果実を生育度分類の対象として, 果 実が含まれる画像を撮影した。 具体的には, 長野県上伊那 郡箕輪町のリンゴ農園内のふじ 60 本，あいかの香り 372 本を対象にして，約 2 週間毎に，任意の果実を撮影した. ふじの栽培方法は, 台木 : M9 丸葉付台木, 樹齢 : 28 年, 栽培間隔 : $2 \mathrm{~m}$, 栽培方法 : わい化栽培である。 また, あ いかの香りは，台木 : M9 台木，樹齢 : 5 年，栽培間隔 : $80 \mathrm{~cm}$ ，栽培方法：高密植わい化栽培である.

撮影は，スマートフォン（iPhone SE，Apple，米国）を 用いて，果実が膨らみだした 2019 年 6 月 6 日に開始し， 収穫直前まで実施した。果実の生育は，通常，果実が膨ら みだしてから収穫直前まで，時間の経過とともに進む．本 研究では, 初回撮影日に撮影した画像をクラス名が 0 のグ ループに設定し，また，初回撮影日以降に撮影した画像は， 撮影日ごとにクラス名を 1 つずつ増加させたグループに設 定した. このように，今回設定したクラス名は，果実の生 育に伴って増加する順序尺度である，果実画像のクラス， 撮影日時, 画像数を表 1 に示す。果実の撮影は, 降雨時括 よび降雨後 24 時間以内を避けた。 また，リンゴ農園のふ じとあいかの香りの収穫日が異なったため, 最終撮影日は 異なった.

\section{作成した画像セット}

本研究では，果実が画像中央に位置して，果実の約 2 倍 以上の周辺領域が含まれる画像を原画像として撮影した。 そして，原画像内の果実を異なる倍率で拡大もしくは縮小 して新たな画像を順次作成し，それらの画像を一定サイズ にリサイズすることで，果実拡大率の異なる画像を作成し た. 具体的には，原画像は，上記のスマートフォンで撮影
表 1 果実画像のクラス, 撮影日時, 画像数

\begin{tabular}{|c|c|c|c|c|}
\hline \multirow{2}{*}{ クラス } & \multirow{2}{*}{ 撮影日 } & \multirow{2}{*}{ 撮影時刻 } & \multicolumn{2}{|c|}{ 画像数（枚） } \\
\hline & & & ふじ & あいかの香り \\
\hline 0 & 06 月 06 日 & $9: 45 \sim 10: 41$ & 107 & 118 \\
\hline 1 & 06 月 13 日 & $9: 06 \sim 10: 07$ & 130 & 140 \\
\hline 2 & 06 月 26 日 & $17: 14 \sim 18: 12$ & 133 & 185 \\
\hline 3 & 07 月 11 日 & $9: 09 \sim 10: 06$ & 132 & 155 \\
\hline 4 & 07 月 24 日 & $9: 02 \sim 10: 00$ & 156 & 180 \\
\hline 5 & 08 月 08 日 & $9: 09 \sim 10: 00$ & 145 & 166 \\
\hline 6 & 08 月 26 日 & $13: 32 \sim 14: 43$ & 174 & 179 \\
\hline 7 & 09 月 06 日 & $9: 24 \sim 10: 39$ & 182 & 191 \\
\hline 8 & 09 月 19 日 & $9: 31 \sim 10: 54$ & 194 & 201 \\
\hline 9 & 10 月 03 日 & $11: 29 \sim 12: 33$ & 187 & 192 \\
\hline 10 & 10 月 17 日 & $11: 28 \sim 12: 33$ & 205 & 215 \\
\hline 11 & 10 月 31 日 & $9: 14 \sim 10: 25$ & 179 & 193 \\
\hline \multirow{3}{*}{12} & 11 月 09 日 & $14: 25 \sim 15: 18$ & - & 273 \\
\hline & 11 月 13 日 & $13: 58 \sim 15: 05$ & 288 & - \\
\hline & & 合計 & 2,212 & 2,388 \\
\hline
\end{tabular}

した横 $3024 \times$ 縦 4032 (pixel) の画像とした. 原画像の撮 影では, スマートフォンの画面にグリッドライン（画面 を9 分割する縦横の 2 本ずつの線）を表示し，このグリッ ドラインで表示される画像中央部分に果実がお括むね位置 するように撮影した. この結果, 原画像は, 画像中央を中

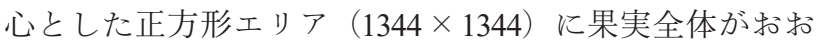
む水位置する画像となった。 そして，その正方形エリアを 果実サイズとし，0.462-6.000 倍の範囲で 13 段階に果実拡 大率（長さ比）を設定して，新たな画像を原画像から切り 出した。例えば，果実拡大率 1.000 の画像は，画像中央を 中心とした $1344 \times 1344$ を切り出した画像になる。 また, 果実拡大率 6.000 の画像は, 画像中央を中心とした $224 \times$ 224 の画像であり, 果実中央部分のみの画像になる。 そ して, 果実拡大率 0.462 の画像は, 画像中央を中心とした $2912 \times 2912$ の画像であり, 周辺領域が大きく含まれる画 像になる。な挔，新たに切り出したこれらの画像は，後述 のCNN に入力するために，一定サイズ $(224 \times 224)$ にリ サイズした. 以下では, リサイズ後の画像を果実画像と呼 ぶ.

作成した果実画像の例（クラスと果実拡大率別）を図 1 に示す。この図から，ふじとあいかの香りともに， クラス の増加にともなって, 形が徐々に変化してゆき, 色彩も変 化してゆくことがわかる。また，あいかの香りはふじより も, 特に収穫前に光沢が強くなっており, 品種の違いと推 察される，次に，らじとあいかの香りともに，果実拡大率 が 1.000 から増加するにともなって, 果実周辺領域が減少 してゆき, 最終的には, 果実表面のみが拡大された画像に なっていることがわかる. 一方で, 果実拡大率が 1 から減 少するにともなって, 果実周辺領域が増加してゆき, 周囲 の葉や枝が多く写り込んでいることがわかる，また，クラ スの増加にともなって葉の形や色彩が変化しており，さら 

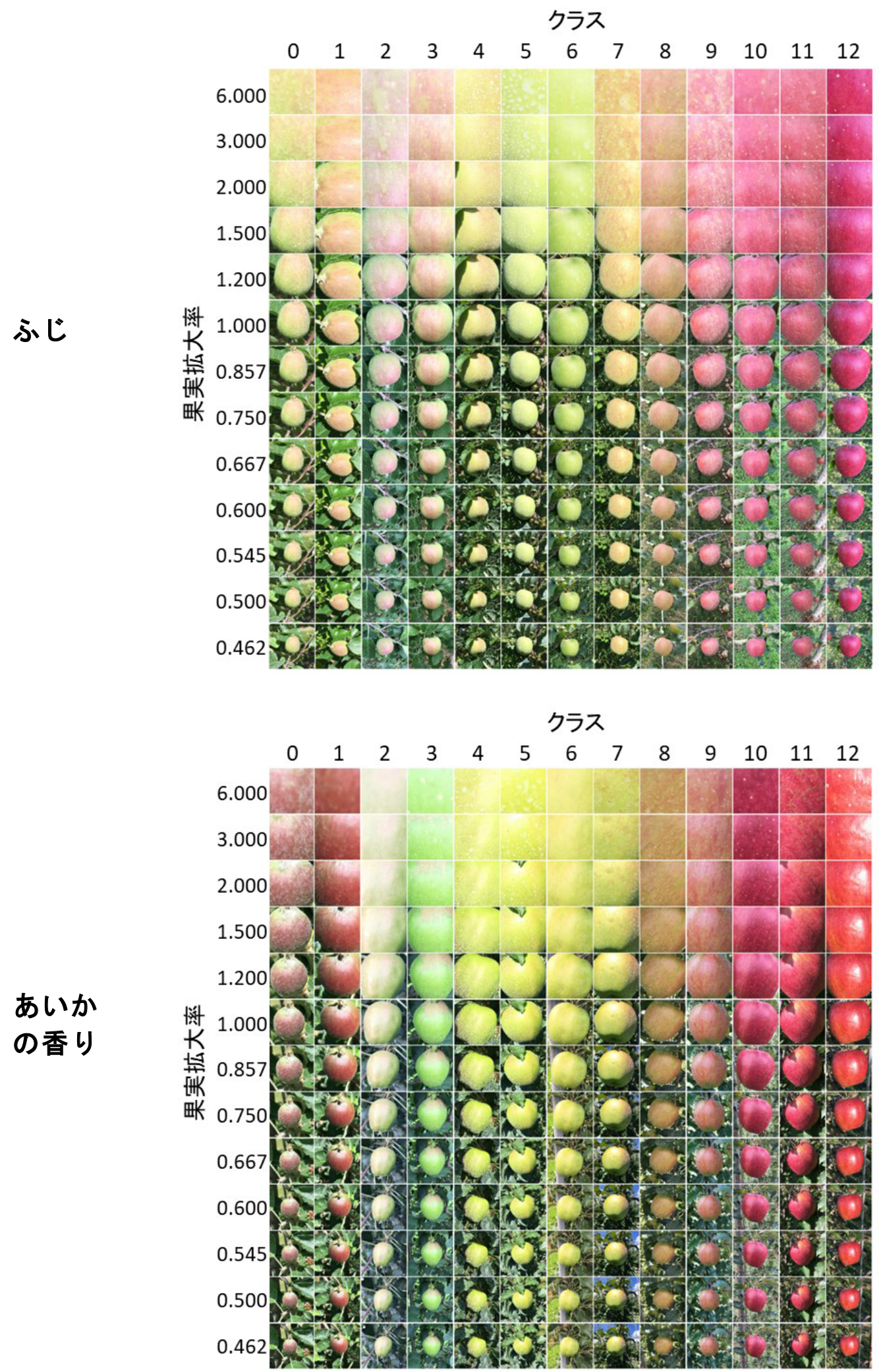

図 1 果実画像の例（クラスと果実拡大率別）

に，クラスの増加にともなって果実が肥大することから， 葉や枝が相対的に縮小されていることがわかる.
果実画像の生育度分類 CNN による深層学習

本研究では，果実画像を高精度で分類するために，高 い画像分類性能が実証されている CNNによる深層学習を 用いた（LeCun et al. 2015）。果実画像を入力して，果実の 


\section{表 2 果実画像分類用の CNN 構造}

\begin{tabular}{|c|c|c|c|c|}
\hline 層番号 & 層の名称（タイプ） & 層の出力形 & パラメータ数 & 学習 \\
\hline 0 & input (InputLayer) & (None, 224, 224, 3) & 0 & 非学習 \\
\hline 1 & block1_conv1 (Conv2D) & (None, 224, 224, 64) & 1,792 & 非学習 \\
\hline 2 & block1_conv2 (Conv2D) & (None, 224, 224, 64) & 36,928 & 非学習 \\
\hline 3 & block1_pool (MaxPooling2D) & (None, $112,112,64)$ & 0 & 非学習 \\
\hline 4 & block2_conv1 (Conv2D) & (None, $112,112,128$ ) & 73,856 & 非学習 \\
\hline 5 & block2_conv2 (Conv2D) & (None, $112,112,128$ ) & 147,584 & 非学習 \\
\hline 6 & block2_pool (MaxPooling2D) & (None, $56,56,128$ ) & 0 & 非学習 \\
\hline 7 & block3_conv1 (Conv2D) & (None, $56,56,256$ ) & 295,168 & 非学習 \\
\hline 8 & block3_conv2 (Conv2D) & (None, $56,56,256$ ) & 590,080 & 非学習 \\
\hline 9 & block3_conv3 (Conv2D) & (None, $56,56,256$ ) & 590,080 & 非学習 \\
\hline 10 & block3_pool (MaxPooling2D) & (None, $28,28,256$ ) & 0 & 非学習 \\
\hline 11 & block4_conv1 (Conv2D) & (None, 28, 28, 512) & $1,180,160$ & 非学習 \\
\hline 12 & block4_conv2 (Conv2D) & (None, 28, 28, 512) & $2,359,808$ & 非学習 \\
\hline 13 & block4_conv3 (Conv2D) & (None, 28, 28, 512) & $2,359,808$ & 非学習 \\
\hline 14 & block4_pool (MaxPooling2D) & (None, $14,14,512$ ) & 0 & 非学習 \\
\hline 15 & block5_conv1 (Conv2D) & (None, $14,14,512$ ) & $2,359,808$ & 学習 \\
\hline 16 & block5_conv2 (Conv2D) & (None, $14,14,512$ ) & $2,359,808$ & 学習 \\
\hline 17 & block5_conv3 (Conv2D) & (None, $14,14,512$ ) & $2,359,808$ & 学習 \\
\hline 18 & block5_pool (MaxPooling2D) & (None, $7,7,512$ ) & 0 & 学習 \\
\hline 19 & global_average_pooling2d & (None, 512) & 0 & 学習 \\
\hline 20 & dense_1 (Dense) & (None, 512) & 262,656 & 学習 \\
\hline 21 & dense_2 (Dense) & (None, 13) & 6,669 & 学習 \\
\hline
\end{tabular}

生育度，すなわち，クラスを出力する CNN は，VGG16 (Simonyan and Zisserman 2015) のファインチューニング（中 山2015）を用いて作成した。VGG16は，画像認識競技 会であるILSVRC（ImageNet Large Scale Visual Recognition Challenge）で 2014 年に提案された CNNであり，Keras の モジュールに組み込まれているために一般に使用できる (Keras Documentation 2020). また，ファインチューニング とは，学習済ネットワークの一部をそのまま用い，それ以 外を必要に応じて変更や追加して学習させることで，学習 済ネットワークを活用しつつ新たなネットワークを開発す る方法である. 今回開発した果実画像分類用の CNN 構造 を表 2 に示す。1-18 層まではVGG16 と同じ構造にして， 入力画像も VGG16 と同じである $224 \times 224$ のカラー画像 とした。また，学習演算の負荷を減らすために，19層目 に Global Average Pooling 層を入れて CNN のパラメータ数 を削減した。 この位置に Global Average Pooling 層を入れる ことにより，パラメータ数を減少でき，乙かも分類精度が 低下しないことが確認されている（Lin et al. 2014）。学習 時には，表 2 に示すように 14 層までのパラメータを固定 し, 15 層目以降のパラメータのみを学習させた。 すなわち, 14 層までのパラメータをVGG16 と同一にすることで汎用 的なネットワークを再利用しつつ，15 層目以降の学習に よってリンゴ果実画像に特化した CNNを作ることをめざ した.

なお，CNNに入力される果実画像は，上述のように，
果実拡大率は異なるが，すべて $224 \times 224$ にリサイズされ ている. 本研究では, 果実拡大率毎に学習を行った.

CNN の学習と検証は, $\mathrm{k}=4$ として $\mathrm{k}$ 分割交差検証 (Koha 1995）を行った。 すなわち, 表 1 に示した画像セット（ふ じ 2212 枚，あいかの香り 2388 枚）を，クラス毎に約 $1 / 4$ ずつランダムに $\mathrm{a}, \mathrm{b}, \mathrm{c}, \mathrm{d} の 4$ グループに分割し, 最初 の試行では $\mathrm{a}, \mathrm{b}, \mathrm{c}$ を学習用画像, d をテスト用画像とし て学習した。 その後, 順次, テスト画像を入れ替えて学習 し, 各果実拡大率について合計 4 回の学習を行った。学 習は，エポック数を 200 に設定し，目的関数は交差エント ロピーを用い, 最適化アルゴリズムは確率的勾配降下法 （SDG）を用いた。 また, 学習率は 0.001 , 慣性項は 0.9 , バッ チサイズは 32 に設定した（Keras Documentation 2020)。こ の学習は, GPU（TITAN X, NVIDIA，米国）を搭載した Windows10 Pro 上の Python（Ver. 3.6.8）に拈いて, バック エンドに TensorFlow-gpu（Ver. 1.12.0）を設定した Keras（Ver. 2.1.2）を使用した。

\section{学習済 CNN による果実拡大率別の分類精度}

学習済 CNNによるテスト用画像の分類結果を, 果実拡 大率別に表 3 に示す。この表では，各果実拡大率につい て, 4 回の分類結果の平均値と標準偏差（SD）を算出し, 平均 $\pm \mathrm{SD}$ を記載している. 分類結果の評価指標には, 正 解率 (Accuracy), 適合率 (Precision), 再現率 (Recall), F 值（Fscore）を用い，適合率，再現率，F 值は，マクロ平 均を用いた。 これらは, 後述する混同行列を含め, Python 
表 3 学習済 CNN によるテスト用画像の分類結果（平均 \pm SD）

\begin{tabular}{ccccc}
\multicolumn{5}{c}{ ふじ } \\
\hline 果実拡大率 & 正解率 (Accuracy) & 適合率 (Precision) & 再現率 $($ Recall $)$ & $\mathrm{F}$ 值 $($ Fscore $)$ \\
\hline 0.462 & $0.788 \pm 0.007$ & $0.799 \pm 0.010$ & $0.781 \pm 0.009$ & $0.776 \pm 0.013$ \\
0.500 & $0.801 \pm 0.016$ & $0.812 \pm 0.017$ & $0.803 \pm 0.016$ & $0.796 \pm 0.020$ \\
0.545 & $0.819 \pm 0.015$ & $0.826 \pm 0.014$ & $0.821 \pm 0.017$ & $0.818 \pm 0.018$ \\
0.600 & $0.809 \pm 0.018$ & $0.819 \pm 0.017$ & $0.808 \pm 0.019$ & $0.805 \pm 0.021$ \\
0.667 & $0.812 \pm 0.017$ & $0.818 \pm 0.018$ & $0.817 \pm 0.019$ & $0.811 \pm 0.021$ \\
0.750 & $0.810 \pm 0.039$ & $0.828 \pm 0.028$ & $0.817 \pm 0.035$ & $0.813 \pm 0.038$ \\
0.857 & $0.809 \pm 0.009$ & $0.818 \pm 0.012$ & $0.816 \pm 0.007$ & $0.811 \pm 0.009$ \\
1.000 & $0.822 \pm 0.018$ & $0.838 \pm 0.017$ & $0.830 \pm 0.018$ & $0.827 \pm 0.018$ \\
1.200 & $0.790 \pm 0.019$ & $0.812 \pm 0.013$ & $0.798 \pm 0.017$ & $0.793 \pm 0.018$ \\
1.500 & $0.767 \pm 0.021$ & $0.781 \pm 0.018$ & $0.776 \pm 0.015$ & $0.772 \pm 0.017$ \\
2.000 & $0.731 \pm 0.015$ & $0.751 \pm 0.013$ & $0.741 \pm 0.011$ & $0.736 \pm 0.013$ \\
3.000 & $0.679 \pm 0.028$ & $0.693 \pm 0.030$ & $0.678 \pm 0.023$ & $0.676 \pm 0.025$ \\
6.000 & $0.594 \pm 0.022$ & $0.606 \pm 0.040$ & $0.579 \pm 0.029$ & $0.576 \pm 0.030$ \\
\hline
\end{tabular}

あいかの香り

\begin{tabular}{ccccc}
\hline 果実拡大率 & 正解率 (Accuracy) & 適合率 (Precision) & 再現率 (Recall) & $\mathrm{F}$ 值 $($ Fscore) \\
\hline 0.462 & $0.862 \pm 0.018$ & $0.877 \pm 0.011$ & $0.864 \pm 0.018$ & $0.863 \pm 0.016$ \\
0.500 & $0.869 \pm 0.024$ & $0.883 \pm 0.019$ & $0.871 \pm 0.028$ & $0.871 \pm 0.025$ \\
0.545 & $0.860 \pm 0.013$ & $0.873 \pm 0.012$ & $0.860 \pm 0.012$ & $0.861 \pm 0.013$ \\
0.600 & $0.868 \pm 0.022$ & $0.884 \pm 0.012$ & $0.868 \pm 0.023$ & $0.868 \pm 0.023$ \\
0.667 & $0.858 \pm 0.024$ & $0.868 \pm 0.021$ & $0.860 \pm 0.023$ & $0.858 \pm 0.025$ \\
0.750 & $0.848 \pm 0.034$ & $0.870 \pm 0.024$ & $0.849 \pm 0.034$ & $0.850 \pm 0.035$ \\
0.857 & $0.865 \pm 0.010$ & $0.882 \pm 0.008$ & $0.867 \pm 0.012$ & $0.868 \pm 0.012$ \\
1.000 & $0.871 \pm 0.008$ & $0.885 \pm 0.013$ & $0.876 \pm 0.009$ & $0.876 \pm 0.009$ \\
1.200 & $0.855 \pm 0.017$ & $0.875 \pm 0.012$ & $0.861 \pm 0.016$ & $0.858 \pm 0.017$ \\
1.500 & $0.834 \pm 0.004$ & $0.850 \pm 0.006$ & $0.841 \pm 0.007$ & $0.837 \pm 0.007$ \\
2.000 & $0.813 \pm 0.020$ & $0.824 \pm 0.019$ & $0.820 \pm 0.023$ & $0.817 \pm 0.023$ \\
3.000 & $0.762 \pm 0.018$ & $0.772 \pm 0.015$ & $0.765 \pm 0.020$ & $0.761 \pm 0.019$ \\
6.000 & $0.698 \pm 0.029$ & $0.709 \pm 0.035$ & $0.695 \pm 0.029$ & $0.693 \pm 0.033$ \\
\hline
\end{tabular}

の Scikit-learn（Ver. 0.22.2）を使用して算出した（Scikit-learn Documentation 2020).

表 3 から，ふじとあいかの香りともに，正解率などの評 価指標は，果実拡大率が 1.000 に達するまでは，果実拡大 率の増加にともなら顕著な変化が見られないが，1.000を 超えてから急激に低下していることがわかる，また，ふじ とあいかの香りを比較すると, 各指標とも, 全ての果実拡 大率で，あいかの香りがふじよりも高くなっていること がわかる，これらの傾向は，正解率，適合率，再現率， F 值で同様であったため，4つの指標を代表して，正解率に ついて統計解析を行った結果を図 2 に示す。統計解析は, SPSS Statistics 25.0 for Windows を用いて行った.

図 2 は，テスト用画像を分類した時の果実拡大率によ る正解率の変化 (平均 $\pm \mathrm{SD}$ ) である。 らじは，一部の果 実拡大率で正解率が正規分布していなかったので，ノンパ ラメトリック検定である Kruskal-Wallis 検定を行った結果, 有意差が認められた（P<0.001）. Dunn test を用いた多重比
較の結果で，有意差が認められたペアを図中に示す。この 有意差検定の結果，果実拡大率 0.545 と 1.000 で，正解率 が高くなり，両者の間では有意差が認められないことが明 らかになった。

あいかの香りは，全ての果実拡大率で正解率が正規分 布して拈り，果実拡大率を要因とした 1 元配置分散分析 を行った結果, 有意差が認められた $(\mathrm{F}(12,39)=19.072$, $\mathrm{P}<0.001$ ）ＬSD を用いた多重比較の結果，有意差が認め られたペアを図中に示す。ただし, 果実拡大率 3.000 と 6.000 は，他の全ての果実拡大率との間で有意差が認められたの で（P<0.01），ペア表示を省略した. この有意差検定の結 果, 果実拡大率 $0.500,0.600,1.000$ で, 正解率が高くなり, この 3 者間では有意差が認められないことが明らかになっ た.

テスト用画像を分類した時の混同行列を図 3 に示す。こ の図では，正解率が高かった果実拡大率の例として，ふじ では 0.545 と 1.000 , あいかの香りでは 0.500 と 1.000 の結 


\section{ふじ}

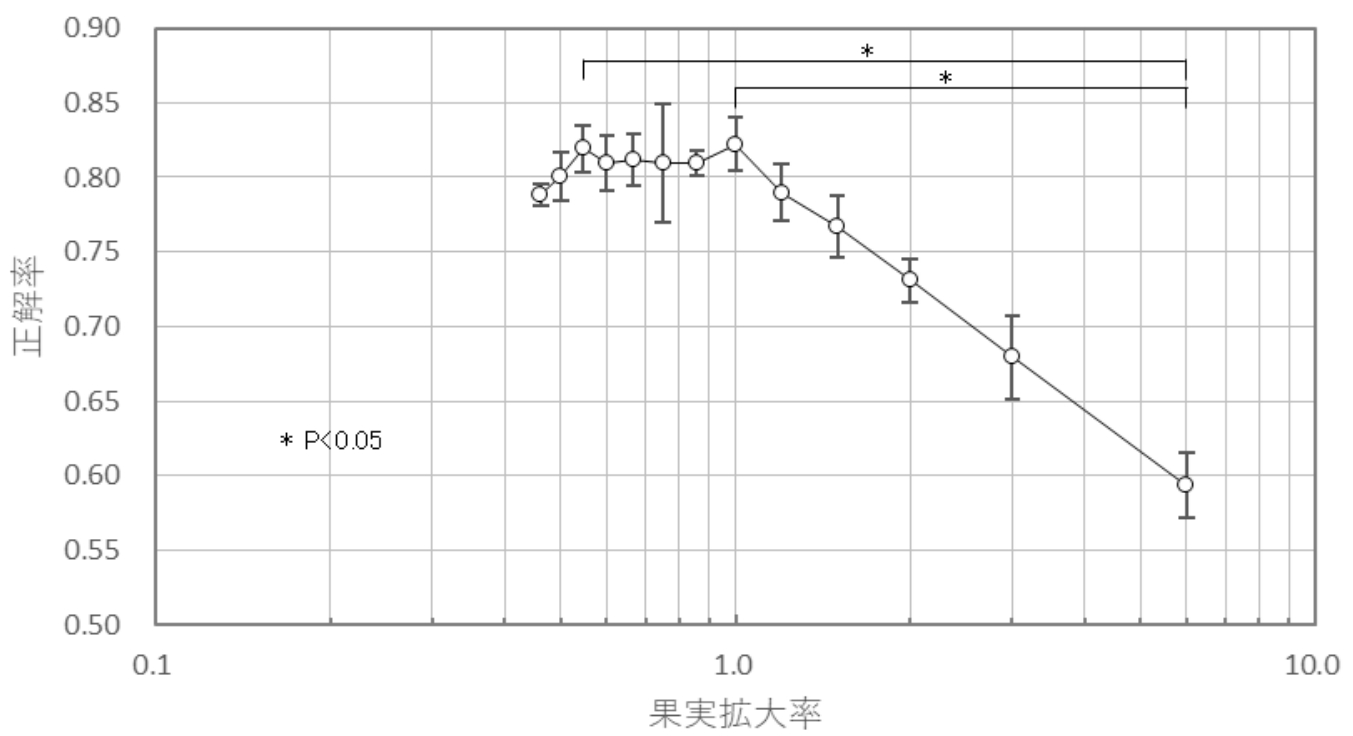

あいかの香り

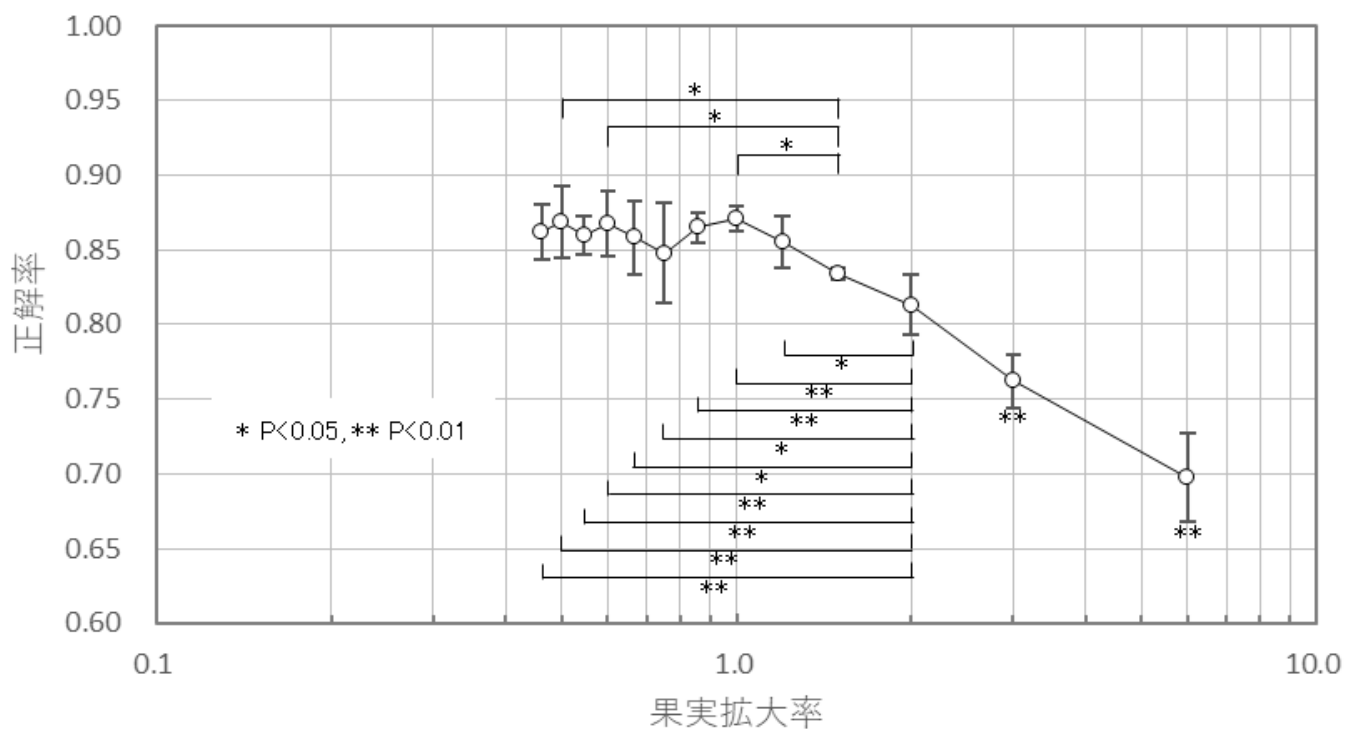

図 2 テスト用画像を分類した時の果実拡大率による正解率の変化（平均 $\pm \mathrm{SD}$ )

果を示す．また，比較のために，ふじとあいかの香りとも に, 正解率が最も低かった果実拡大率 6.000 の結果も示す. 混同行列は，各果実拡大率について，k 分割交差検証によ る 4 回の分類結果を統合して作成した。具体的には，4回 の分類で用いた全てのテスト用画像について，真のクラス ごとに予測クラス別の数を求め, 真のクラスごとに合計が 1.0 になるように正規化した。 また，図中の色は，紺色か ら黄色に変化するほど,高い割合であることを示して抢り， 正規化した数值も併記した.

この図から，ふじでは果実拡大率 0.545 と 1.000 の時に, あいかの香りでは果実拡大率 0.500 と 1.000 の時に, 誤分 類が少なく，真のクラスと大きく異なる予測をすることが
ほとんどないことがわかる。一方，ふじとあいかの香りと もに，果実拡大率 6.000 の時は誤分類が多く，特に，ふじ では，真のクラスと大きく異なる予測をする場合が多いこ とがわかる。

\section{スマートフォンを用いた果実画像の自動生育評 価}

上述のように，CNN に果実画像を入力して生育度を分 類する際に正解率が高くなる果実拡大率は, ふじは 0.545 と 1.000 ，あいかの香りは $0.500,0.600 ， 1.000$ であった. このことから，CNN で高い正解率を得るためには，少な 
ふじ

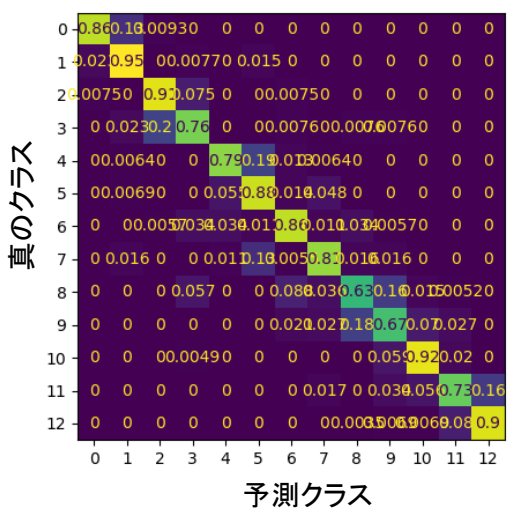

果実拡大率 0.545

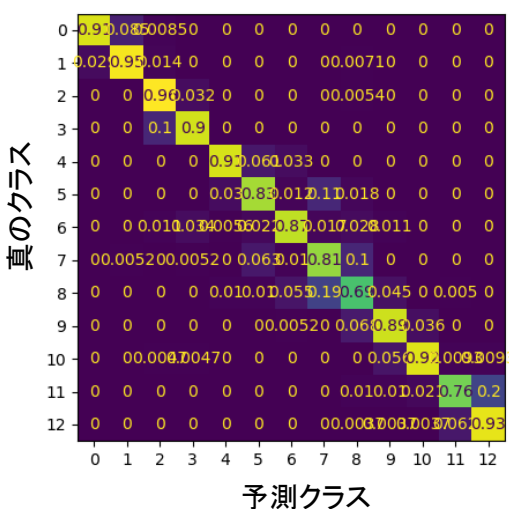

果実拡大率 0.500

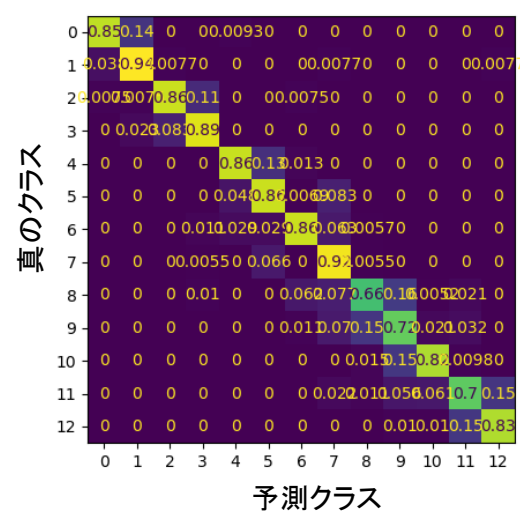

果実拡大率 1.000

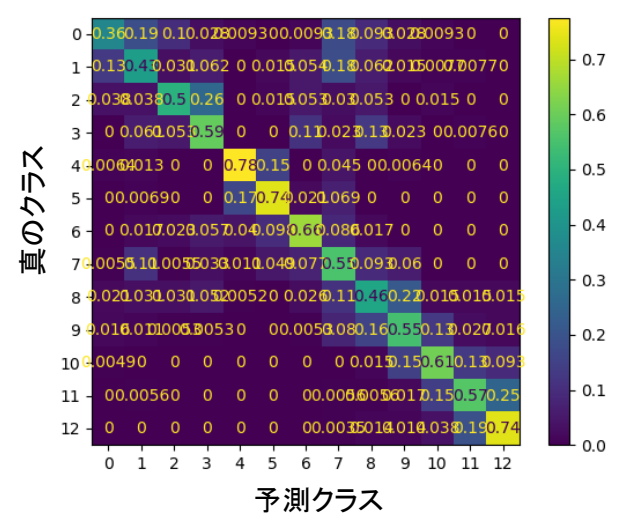

果実拡大率 6.000

\section{あいかの香り}

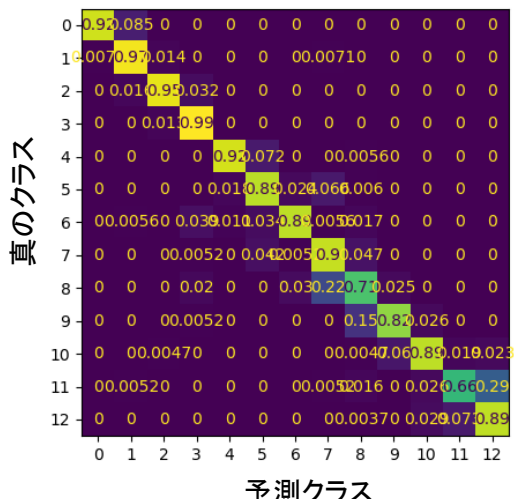

果実拡大率 1.000

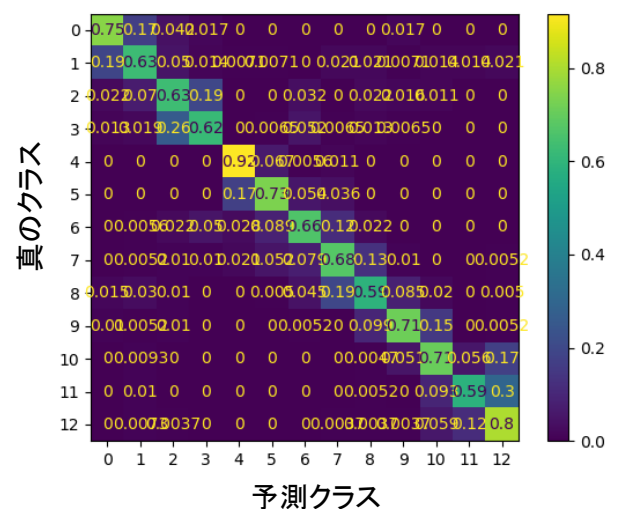

果実拡大率 6.000

図 3 テスト用画像を分類した時の混同行列

くとも，果実全体が写っている画像を入力する必要がある と推察される。 また，両品種ともに，果実拡大率 1.000 の ときに正解率が高かったことから，本研究では，スマート フォンで果実を撮影した時に，果実拡大率が約 1 倍になる 果実画像が自動で切り出され, 推定生育度が自動表示され るアプリケーションを試作した. 以下では, システム構成 とアプリケーションの例を示す.

\section{システム構成}

本研究では, 推定生育度が自動表示されるアプリケー ションを生育評価アプリケーションと呼び, 生育評価アプ リケーションを搭載したシステムを生育評価システムと呼 ぶ. 図 4 に, リンゴ果実の生育評価システムの構成例を示 す。 システムは, Webサーバ，生育評価アプリケーショ ン, スマートフォンから構成される. 生育評価アプリケー ションは, フロントエンドに HTML5, CSS3, JavaScript を，バックエンドに Python（Ver. 3.6.8）を用いて構築した. Python では，受信した原画像に対して，物体抽出方法であ る Yolo（Ver. 4, Bochkovskiy et al. 2020）を用いて，果実拡 大率が約 1 倍になる正方形の果実画像を抽出する. これを 可能にするために, Yolo の学習では, 著者らが定点計測（源
野，小林 2017, Genno and Kobayashi 2019）して得た 2016 年のリンゴ樹画像 $(5184 \times 3456,3281$ 枚 $)$ から，果実が 含まれる任意の画像 $(416 \times 416,637$ 枚 $)$ を切り出し, 画 像内に含まれる合計 2402 個の果実に対して, 果実の輪郭 に合わせて正方形でアノテーションを付けて学習させた。 また, Yoloで物体抽出する元画像のサイズは縦横とも に 32 の倍数にする必要があるため, ここでは, スマート フォンで撮影した原画像 $(3024 \times 4032)$ の中央部分 3008 ×3008 を対象にした。 そして, Yolo が抽出して $224 \times 224$ にリサイズされた果実画像は，Pythonの Keras（Ver. 2.1.2） と TensorFlow-gpu（Ver. 1.12.0）で作成して上述のように学 習したCNNに入力されて, 生育度分類が行われる。学習 済 $\mathrm{CNN}$ の出力結果, すなわち, 推定生育度は, 非同期通 信でフロントエンドに送信される.

\section{生育評価アプリケーション}

生育評価アプリケーションのスマートフォンでの画面 例を図 5 に示す。ユーザが Web サーバにアクセスすると, 写真撮影画面が表示される，写真撮影画面では，ガイドフ レーム（画像中央の白枠）が表示され，また，「果実がガ イドフレームに扮拈むね一致するように撮影してくださ 


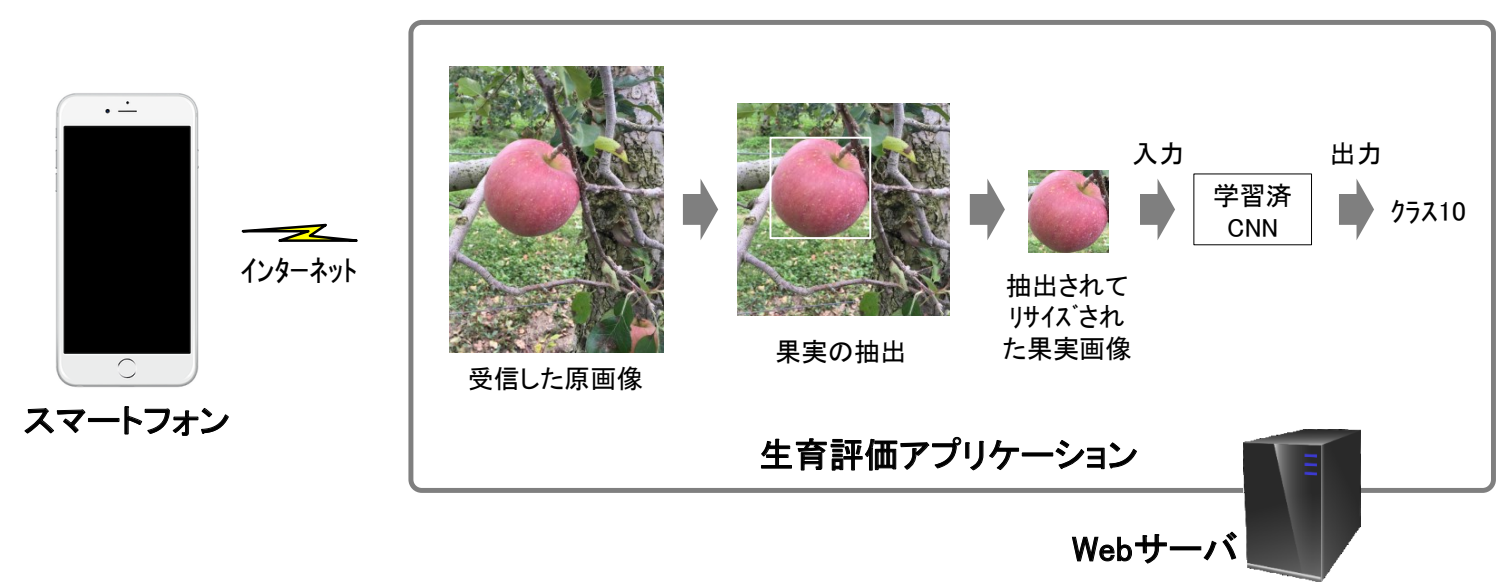

図 4 リンゴ果実の生育評価システムの構成例

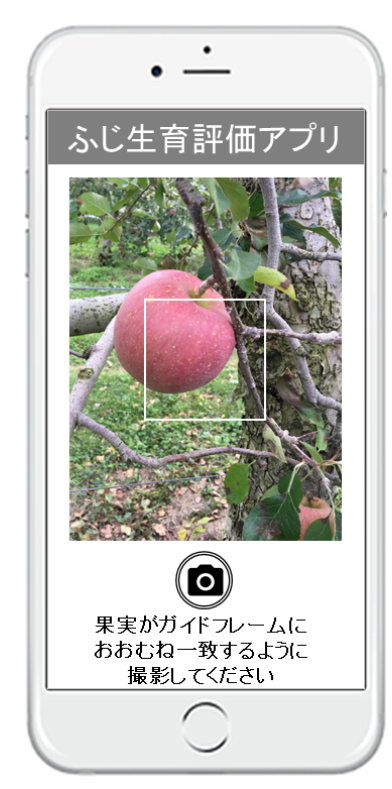

写真撮影面面

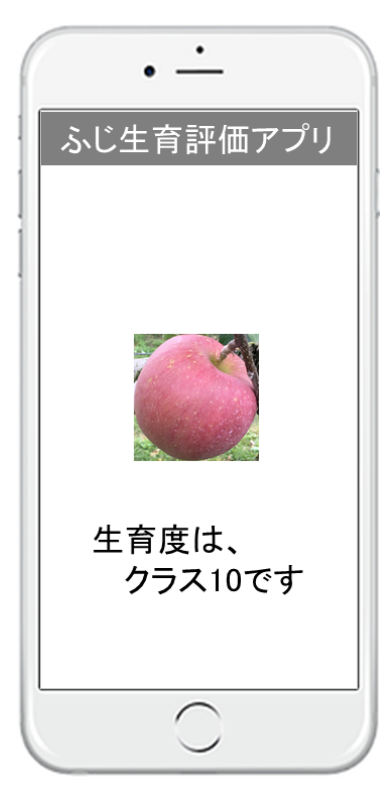

生育度受信画面
図 5 生育評価アプリケーションの画面例

いよいら文字が表示される. 本アプリケーションの場合, ガイドフレームは，原画像に対する面積比で約 $1 / 9$ の正方 形にして，画像中央に表示している。 この表示は，ユーザ が果実を画像中央で撮影しやすくする配慮である. しかし， 実際には果実が画像中央から外れる場合も多いと想定し， 上記の物体抽出方法 Yolo で果実を抽出するようにした. この結果, 果実がガイドフレームから外れていても, Yolo で物体抽出する元画像（原画像の中央部分 $3008 \times 3008 ）$ に果実全体が写っているかぎり，果実拡大率が約 1 倍にな る果実画像を切り出すことができた.

写真撮影画面でユーザが構図を決定して, 画面中央下部 のカメラボタンを押せば, 写真が撮影されて Web サーバ に自動送信される. その結果, 自動で生育度受信画面に切 り替わり，CNNに入力された果実画像と CNN が出力した 推定生育度が表示される。

\section{考察}

本研究では, リンゴ果実の拡大率を 0.462-6.000 に変化 させた果実画像を用いて, CNNによる生育度の分類精度 を調べた。この結果，正解率が高くなる果実拡大率は，孔 じは 0.545 と 1.000 , あいかの香りは $0.500,0.600,1.000$ であっ た.これらの画像は 1.000 以下の果実拡大率であり, 少な くとも果実の周辺領域が存在し, かつ, 果実全体が写って いる画像であった。したがって，CNN が生育度分類を行 ら際には, 果実の色彩だけではなく, その輪郭や周辺領域 を参照していると推察された。

一方で, 両品種とも, 果実拡大率が 1.000 から増加する にともなって，正解率が減少してゆく傾向が見られた，拡 大率が増加すれば，果実表面の微細な色合いやテクスチャ が得られるものの，果実全体の色彩分布情報は失われる. したがって，CNNが生育度分類を行ら際には，果実全体 の色彩分布を参照していると推察された。

また, 両品種ともに, 果実拡大率 1.000 のときに正解率 が高く，この果実拡大率は，トマト（Zhang et al. 2018）や ウメ（建本ら 2019）の成熟度を分類する先行研究で用い られた入力画像の果実拡大率である。したがって，これら の先行研究は CNN の性能を十分に活用した研究であった といえる.

なお，ふじとあいかの香りの比較では，正解率は，全て の果実拡大率で，あいかの香りがふじょりも高かった。こ れは，収穫前にあいかの香りの光沢が強くなるなど， CNN が画像分類する際に有効な特徵量が，あいかの香りがふじ よりも多かったからだと推察される.

本研究では，スマートフォンで果実を撮影した時に，果 実拡大率が約 1 倍になる果実画像が自動で切り出され, 推 定生育度が自動表示される生育評価アプリケーションを例 示した. このアプリケーションは，リンゴ栽培者を主たる ユーザと想定しており，簡便に素早く任意のリンゴの生育 評価を行らことが目的である. このように, 研究成果を 実用化して農業現場で活用してゆくことが重要と捉えてい るが, このアプリケーションは, 本研究で果実の撮影に使 
用したスマートフォンを想定して抢り，機種ごとに異なる 解像度や撮像素子の特性を考慮していない。 また，このア プリケーションを使用した時に，本研究結果と同様の正解 率が得られるかどらかの検証や，多くのユーザが生育度分 類に必要な原画像を容易に撮影できるかどうも検証してい ない. 今後は, このアプリケーションを多くの機種に対応 できるように改良し，多くのリンゴ栽培者に使用していた だいて, 分類精度や操作性の検証を進めてゆく予定である.

\section{まとめ}

本研究では, CNN を用いてリンゴ果実画像の生育度分 類を行う際に, 分類精度に対する果実拡大率の影響を調査 した. 果実拡大率を0.462-6.000に変化させた結果，ふじ は 0.545 と 1.000 , あいかの香りは $0.500,0.600,1.000$ の 時に正解率が高くなった. また, 両品種とも, 果実拡大率 が 1.000 から増加するにともなって正解率が減少した。 こ れらから，CNNが生育度分類を行ら際には，果実の輪郭 や周辺領域を参照して扣り, また, 果実全体の色彩分布を 参照していると推察された. また, 両品種ともに, 果実拡 大率 1.000 のときに正解率が高かったことから，スマート フォンで果実を撮影した時に，果実拡大率が約 1 倍になる 果実画像が自動で切り出され, 推定生育度が自動表示され る生育評価アプリケーションを例示した。

\section{謝辞}

本研究で，リンゴの果実画像を撮影させていただいたり ンゴ農園（信州のりんご与古美）の伊藤剛史様に謝意を 表します。

\section{引用文献}

新居直祐（1998）果実の生長と発育 1 章 : 果実の発育過程の解析 法及び 3 章 : 果実の肥大成長 3.6 りご, 朝倉書店 : 1-17 及 び 102-106.

Bochkovskiy, A., C. Wang and H. M. Liao (2020) YOLOv4: Optimal Speed and Accuracy of Object Detection, 〈https://arxiv.org/abs/2004.10934〉, 2020 年 12 月 4 日参照.

福田博之，森山修実（1997）收穫期におけるリンゴ果実の大きさ と果肉細胞径の関係，園芸学会雜誌 66（1）：185-188.

源野広和, 小林一樹（2017）大量高精細画像からの果実生育情報
の抽出，農業情報研究，26（4）：100-114.

Genno, H. and K. Kobayashi (2019) Apple Growth Evaluated Automatically with High-Definition Field Monitoring Images, Computers and Electronics in Agriculture, 164: 104895.

Keras Documentation (2020) 〈https://keras.io/〉, 2020 年 1 月 29 日参照. 岸知彦, 加藤幸, 森奈緒子, 佐藤江里子, 土居良一, 溝口勝 (2010) 簡易モニタリングシステムによるリンゴ収穫適期の判断方 法, H23 農業農村工学会大会講演会講演要旨集 : 792-793.

Koha, R. (1995) A Study of Cross-Validation and Bootstrap for Accuracy Estimation and Model selection, IJCAI'95 Proceedings of the 14th international joint conference on Artificial intelligence, 2: 1137-1143.

小池洋男, 吉沢しおり, 塚原一幸（1990）リンゴわい性台樹 の適正着果量と乾物生産の分配, 園芸学会雜誌, 58 (4) : 827-834.

草田育美，石井雅樹，山根治起（2016）屋外に抢活る果実収穫適 期判定を目的とした画像補正手法に関する検討, 日本知能情 報ファジィ学会第 26 回ソフトサイエンス・ワークショップ 平成 27 年度東北支部研究会講演論文集 : 60-63.

LeCun, Y., Y. Bengio and G. Hinton (2015) Deep learning, Nature, 521: 436-444.

Lin, M., Q. Chen and S. Yan (2014) Network in Network, Proceedings of International Conference on Learning Representations (ICLR).

宮本久美（2007）果樹の生育診断への近赤外分光法の応用, 農業 機械学会誌, 69 (3) : 11-14.

守谷（田中）友紀, 岩波宏, 花田俊男, 本多親子, 和田雅人 (2016) リンゴの摘果時間と果実重に及ぼす薬剂摘花・摘果の影響, 園芸学研究, 15 (3) : 283-289.

中山英樹（2015）深層畳み込みニューラルネットワークによる画 像特徵抽出と転移学習, 信学技報, 115 (146)：55-59.

Scikit-learn Documentation (2020)〈https://scikit-learn.org/〉, 2020 年 4 月 15 日参照.

Simonyan, K. and A. Zisserman (2015) Very Deep Convolutional Networks for Large-Scale Visual Recognition, International Conference on Learning Representations.

建本聡, 原田陽子, 今井健司（2019）深層学習を利用したウメ「露 茜」の画像による熟度分類, 農業情報研究 28（3）：108-114.

山本隆儀, 須貝恵美，仁井田貴之（1996）リンゴおよびオウトウ 品種の果実肥大特性と裂果感受性との関係, 園芸学会雜誌 64 (4) : 787-799.

Zhang, L., J. Jia, G. Gui, X. Hao, W. Gao and M. Wang (2018) Deep Learning Based Improved Classification System for Designing Tomato Harvesting Robot. IEEE Access, 6: 67940-67950.

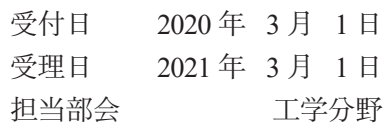




\title{
Effect of Expansion Rate of Fruit Area on Fruit Growth Classification Using Convolutional Neural Networks
}

\author{
Hirokazu Genno*1) and Kazuki Kobayashi' ${ }^{2)}$ \\ 1) Kissei Comtec Co., Ltd., 4010-10 Wada, Matsumoto City 390-1293, Japan \\ 2) Graduate School of Science and Technology, Shinshu University, 4-17-1 Wakasato, Nagano City 380-8553, Japan
}

\begin{abstract}
The purpose of this study was to clarify the effect of the expansion rate of fruit area on the classification of fruit growth using convolutional neural networks (CNNs). The fruit images used in this study were of Fuji and Aikanokaori apples. The images were taken every two weeks from the time the fruit began to swell to the time just before harvest. A growth level was manually assigned to each fruit image as a numerical value based on the date the image was taken. The fruit expansion rate of the fruit image was set from 0.462 to 6.000 in 13 stages, and the CNNs were trained for each fruit expansion rate. Test images were then classified using the learned CNNs, and the accuracy was high when the fruit expansion rate was 0.545 and 1.000 for Fuji and 0.500, 0.600, and 1.000 for Aikanokaori. In both cultivars, the accuracy decreased as the fruit expansion rate increased past 1.000. From these results, we inferred that CNNs refer to the fruit contour and the surrounding area and also to the color distribution of the whole fruit when classifying fruit growth. Because the accuracy was high when the fruit expansion rate was 1.000 in both cultivars, this study exemplified a growth evaluation application in which a fruit image with a fruit expansion rate of 1.0 was successfully extracted automatically. Moreover, the estimated growth rate was automatically displayed when the fruit was photographed with a smartphone.
\end{abstract}

\section{Keywords}

deep learning, convolutional neural network, growth evaluation, application, apple, fruit image

* Corresponding Author

E-mail: genno@comtec.kicnet.co.jp 